\title{
Enhancing Organizational Resilience Through Corporate Social Responsibility
}

\author{
OGA, Kelechi Charles *, EVWIERHURHOMA, Ejiroghene Daniel ** \\ * PhD Student, Department of Management, Faculty of Management Sciences, University of Port Harcourt, Nigeria. \\ ** PhD Student, Department of Management, Faculty of Management Sciences, University of Port Harcourt, Nigeria. \\ DOI: $10.29322 /$ IJSRP.10.12.2020.p10808 \\ http://dx.doi.org/10.29322/IJSRP.10.12.2020.p10808
}

\begin{abstract}
To survive, persist and even thrive in the face of unexpected changes represents significant challenges for organizational decision-makers and have resulted in calls for understanding and developing mechanisms of coping with uncertainty. Thus, the aim of this paper is to examine the relationship between corporate social responsibility and organizational resilience of oil and gas firms in Rivers State, Nigeria. The predictor variable is corporate social responsibility which was used as a uni-dimensional variable while the criterion variable is organizational resilience which was used without measures. The study adopted a correlational and cross-sectional research design and uses questionnaire as the research instrument which was distributed to 50 top executives of ten selected oil and gas firms in Rivers State, Nigeria which comprises of five executives from each oil and gas firms. The data generated were analyzed through the use of Spearman's Rank Order Correlation Coefficient as well as t-statistics to test the relationship between the variables of the study through the use of Statistical Package for Social Sciences within a significance level of 0.05 . The findings showed that corporate social responsibility has positive and significant effect on organizational resilience of oil and gas firms in Rivers State. We therefore recommend among others that oil and gas firms should balance and address the needs of different stakeholders in order to enhance their level of resilience during environmental changes.
\end{abstract}

Index Terms- Corporate Social Responsibility; Organizational Resilience

\section{INTRODUCTION}

$T^{2}$ he business environment of all organizations including oil and gas firms has today become very turbulent and uncertain, thus, one of the major challenges today's business organizations are facing is to develop a new organizational form with the capacity to constantly respond and adapt to environmental changes. Countries globally as well as communities and business enterprises even individuals are all affected by environmental changes. Consequently, the need to incessantly align to changes in the environment has become so essential today than ever due to frequent changes in the business environment brought about by increased globalization. Today, a slight changes in the business environment of any country can have great impacts on the performance of other business organizations in other parts of the world due to the interconnectivity, dependability and interrelatedness of the world business environment mostly enhanced by advanced technology. Hence, an event in one area can often have disastrous effects in another. Incidences like natural disasters, pandemic diseases such as the current covid 19 pandemic, and economic recession can all pose volatile and austere threat to the existence of any given business enterprise.

Therefore, it has become very obvious and glaring that no organization in today's business environment be it profit or nonprofit oriented, local or global and large or small is immune to environmental changes. Thus, Hoopes and Kelley (2004) expressed that the amount of changes that have occurred in the business environment over the last two decades has increased tremendously. In this face of tremendous environmental changes, there is need for organization to be more resilient in their day to day operation in other to be able to attain their set goals and objectives. Organizational resilience has to do with the capability of an organization to bounce back from negative experiences by adapting to the business environment in a flexible manner using its available resources (Grote, 2009). It is a potential remedy to moving beyond survival to organizational prosperity and success in the face of challenging conditions and turbulences. Thus, Denhardt and Denhardt (2010) expressed that since resilience is the ability of business enterprise to recover from challenges to move beyond survival to organizational prosperity and success in the face of challenging conditions in a way that allows the business firm to be more flexible in adapting to future challenges, managers of all organization must find means to promote it at all times. In a bit to promoting the organizational capability of resilience, there is need for the organization to meet the needs of its stakeholders. This is very important as no organization exist in a vacuum; thus organization exist in an environment that lots of persons and institutions have stake as such their interest must be met and satisfied at all times for the organization to be resilient in its operation and generally prosper. In other words, organizations must of necessity engage more in corporate social responsibility.

The practice of corporate social responsibilities in the corporate world has brought a new shape to the social and economic setting throughout the globe (Kamrujjaman \& Muhammad, 2015). This is because the business world is growing rapidly, demanding the organization's competence and public reputation in maintaining their business (Novrianty \& Ely, 2015). Corporate social responsibility is the obligation which a firm has to satisfy the interest of its shareholders as well as to meet the needs of the society at large (Pearce \& Robinson, 2011) which includes its customers, host community as well as government. It 
reflects the organization's value which is based on the economic aspect, social aspect, and environmental aspect to ensure the sustainability of the organization. Thus, corporate social responsibility is a way organizations manages their businesses with a view to making positive and healthy impact on the society, through their economic, environmental and social activities. It is a business strategy meant to assist firms strike a balance between the need to achieve economic and financial objectives and the socio-environmental impact of their activities. To develop and enhance the performance of an organization does not only require it to meet only the need of its shareholders or investors but also the need of its host government and the entire society. This is because, the existence and impact of corporate activities does not only affect the organization but host of other institutions. Therefore, managers must not only focus on the organization's interests, but also consider the interests of parties outside the organization. More so, the survival of every business depends on the accomplishment of its objectives and according to Hilda, Hope and Nwoye (2015) there are two broad categories of business objectives expected to be accomplished vis-à-vis economic objectives and social objectives. While economic objectives are the targets to be accomplished in the marketing efforts of an organization towards enhancing its profitability, social objectives are associated with the aims of an organization towards satisfying the interest of its stakeholders. The capability to meet the interest of all stakeholders plays an important role in ensuring organizational resilience.

Furthermore, the oil and gas industry is one of the largest sectors in the world based on the monetary contribution estimated at $\$ 3.3$ trillion annually that is very essential to the global economic framework (Appiah-Adu \& Amoako, 2016). Also, the oil and gas sector is a major driver of the Nigerian economy due to its contribution in the creation of employments as well as a major source of revenue of the Nigerian economy. However, in the last few months, a series of events and changes such as covid 19 pandemic has profoundly altered the operating environment in the oil sector changing the way they operate. Thus, firm in the oil and gas supply chain have gone from boom to bust. As a result, oil and gas companies are seeing business evaporate. Also, over the years the oil and gas sector have been accused of negligence of providing some basic social responsibility especially to their host communities. As a result, these companies suffers lots of setback that arises from community protest as well as lock down. There is therefore the need to study how the provision of social responsibility by oil and gas firms will impact on their organizational resilience in Rivers State. Thus, the purpose of the study is to determine the relationship between corporate social responsibility and organizational resilience of oil and gas firms in Rivers State, Nigeria. The research question is: what is the relationship between corporate social responsibility and organizational resilience of oil and gas firms in Rivers State, Nigeria? While the research hypothesis is that there is no significant relationship between corporate social responsibility and organizational resilience of oil and gas firms in Rivers State. Nigeria.

\section{LITERATURE REVIEW}

\section{Theoretical Framework}

This publication is licensed under Creative Commons Attribution CC BY

http://dx.doi.org/10.29322/IJSRP.10.12.2020.p10808
This study is anchored on legitimacy theory which place emphasis on the continual endeavour of organizations to make sure they are seen to be operating and functioning in conformity within the society's norms they operate (Deegan, 2009). The theory further emphasize that there is an existence of social contract between business enterprise and the society in which it carries out its operation (Deegan \& Samkin, 2009); this contract can be implicit or explicit as regards to societal expectations. The legal requirements by which a business organization operates is termed explicit while societal or community expectations is termed implicit. Generally, legitimacy theory focused on the relationship between the business organization and the community it operates within and the theory contends that business enterprise can only exist and survive if the society they operate in perceives them to be functioning within the values and norms that conforms to the value system of the society (Gray, 2010). Thus, business organizations must make sure good relationship exist between them and the society which they operate so as to maintain and sustain a good state of legitimacy by which the community permits the continuous existence of the organization even in times of disruptions and turbulences. This is because, no business enterprise exist in a vacuum; thus, its activities depends on the society. Therefore, the legitimacy level of the business enterprise is very essential to its continued survival.

\section{Corporate Social Responsibility}

The business organization's environment has become encircled by different groups of persons and institutions who has stake in the organization as well as have sentient thought on how the business organizations could enhance their image publicly and help in developing and sustaining the society (Carroll \& Shabana, 2010). Thus, this cautious awareness of these group of persons and institutions led to the creation of corporate social responsibility agitating that business organization should be responsible to the social and environmental consequences of their operations and not only to their economic activities. In other word, corporate social responsibility balanced shareholders and other stakeholders' needs. It thus, means that corporate social responsibility goes beyond the traditional obligation of satisfying the need of shareholders to other stakeholders to the organization. Over the years different scholars and managers have dedicated lots of thoughtfulness towards defining corporate social responsibility as a concept due to its complexity. In the words of Bani-khalid and Ahmed (2017) responsibility is a commitment or an obligation between two or more parties which is centered on mutual benefits. Combining the two words, Wartrick and Cochran (1985) earlier defined corporate social responsibility as a business organization's configuration of principles of social obligation, processes of social responsiveness, and policies, programs, and observable outcomes as they relate to the organization's societal relationships. It is a set of suitable behaviours exhibited towards different stakeholders of an organization which can be internally or externally as a result of the organization's sense of obligation towards the impact of its operations on the society in which it operates (Hohnen, 2007; Friedman \& Miles, 2006). Also, McWilliams and Siegel (2001) observed that corporate social responsibility is a situation whereby firms engages in actions that further social good which is beyond the interest of the firm and that which is required by law. Therefore, social responsibility can be seen as the systematic 
objective and intelligent concern shown by the organizational management towards the welfare of members of the society. It restrains individual and organization from destructive activities on humanity. It is the obligation of organizational decision makers to enact and implement managerial behaviours, which protect and improve the interest of the society and the organization that is being socially responsible (McWilliams \& Siegel, 2001).

Corporate social responsibility also include incorporating social characteristics into products and manufacturing processes (by using environmentally-friendly technologies), adopting progressive human resources management practices (by promoting employee empowerment), achieving higher levels of environmental performance through recycling and reducing pollution (by adopting an aggressive stance towards reducing emissions), and advancing the goals of community organizations. It is becoming an increasingly important activity to businesses nationally and internationally. As globalization accelerates and large corporations serve as global providers, these corporations have progressively recognized the benefits of providing corporate social responsibility programs in their various location (Wasserman, 2003). This is because, the provision of social responsibility does not only affect the operations and the performance of the organization but also its survival capability. As such, Ehsan, Kaleen and Jabeem (2012) suggests that the first important goal of the organization is to fulfill its economic aims, thereafter its social aims. The economic responsibility of an organization is to ensure the production of goods and services desired by society and make profit out of it (Carroll, 1979). The economic responsibility has to do with profit maximization of the organization which according to Friedman (1970) is the primary and sole responsibility of any business organization. Thus, managers should only be responsible in enhancing the profitability of the organization through effective and efficient deployment of its resources as well as engaging in activities that will enhance its profits as long as the organization acts within the confined of laws or rules. On the other hand, social responsibility means being accountable for the social effects the organization has on people and institution even indirectly which include the organization's customers, suppliers, distributors, host community, government and other stakeholders. It is an organization's responsibility to make choices and take actions that will add value to the society at large as well as those of the organization (Hossain, Salat \& Amin, 2005) by doing what is right, just and fair. The ability of an organization to do what is right, just and fair plays an important roles in enhancing the public image of the organization thereby increasing their market levels and subsequently increasing their performance.

\section{ORGANIZATIONAL RESILIENCE}

Resilience is fundamentally a nascent characteristics connected with a business firm's capability to attain its goal(s) and objective(s) in the face of interference and turbulence through adaptive capacity, situation awareness as well as innovation. It is the ability of business enterprise to align or adapt its activities and operations to environmental changes in times of difficulty and challenges so as to achieve enhanced organizational performance and recover more swiftly to better performance level subsequent to dwindling performance through characteristics of mindfulness, training and agility (Antunes \& Mourao, 2011; Deevy, 1995). Thus, organizations build resilience capacity in order to lessen the effect of deleterious changes from its environment as well as the capacity to recuperate to an enhanced organizational performance after a performance decline. Organizational resilience is an essential if not critical element in the success of any organization. It is therefore, essential for managers to build organization's levels of resilience that will not only help to acclimatize with changes that might spring from the business environment by minimizing the level of disruption it might bring to the organization, but to see changes as a usual and normal ways of attaining set goals and objectives.

Furthermore, according to Robb (2000), a business organization with a resilient capability is able to maintain and enhance its competitive advantage over time by delivering excellent performance against set goals as well as effectually innovating and adapting to swift and uncertain changes from the business environment. It also exhibits certain broad characteristics, and is able to create structure and dissolve it when necessary, provide safety (though not necessarily security or stability) during times of change, manage the emotional consequences of continuous change through continuous learning, developing and growing. The frequent changes in the business environment vis-à-vis technological changes, economical changes, social and political changes has today makes it very challenging for any business enterprise to carry out their operation seamlessly. Thus, old methods of operation is gradually becoming outdated and quickly reducing the performance of the organization. Deevy (1995) expressed that this unstable and uncertain business environment needs managers to understand more deeply the inner dynamics of the organizations, hence, there is need to for business organizations to be more resilient such as time as this.

\section{Methodology}

Correlational vis-à-vis cross sectional survey research design was adopted in this study in order to determine the level of relationship that exist between corporate social responsibility and organizational resilience of selected oil firms in Rivers State, Nigeria. The independent variable is corporate social responsibility used as a uni-dimensional variable while the dependent variable is organizational resilience which was also used as a single variable without measures. More so, the study adopts questionnaire as the research instrument which consist of four respond choices with 5 Point Likert scales ranging from 1 to 5 indicating strongly disagree, disagree, indifference, agree and strongly agree respectively. Face and content validity was also used for the validity of the research instrument while the reliability of the research instrument indicates a Cronbach Alpha value higher than 0.7; specifically the values for corporate social responsibility $=0.941$ while that of organizational resilience $=$ 0.927. The population of this study was made up five (5) managers from strategic departments of ten (10) selected oil and gas firms operating in Rivers State, Nigeria vis-à-vis (human resource department, finance department, marketing department, operations department and public relations department). Therefore, the population of the study consists of 50 managers of the 5 identified departments of the ten (10) selected oil and gas 
firms which were also used as the sample size. From the 50 questionnaire distributed, 47(94.00\%) copies of questionnaire were retrieved while the remaining $3(6.00 \%)$ were not retrieved. More so, all the 47 questionnaire retrieved were used for data analysis. The retrieved data were analyzed through the use of Spearman's Rank Order Correlation Coefficient Statistical as well as t-statistics to test the relationship between corporate social responsibility and organizational resilience with the aid of Statistical Package for Social Sciences (SPSS) Windows version 25 within a significance level of 0.05 .

\section{DATA ANALYSIS AND RESUlts}

The Strength of the Relationship between Corporate Social Responsibility and Organizational Resilience

Table 1: Correlation between corporate social responsibility and organizational resilience

\begin{tabular}{|c|c|c|c|c|}
\hline & & & \multicolumn{2}{|c|}{ Corporate SocialOrganizationa } \\
\hline & & & Responsibility & Resilience \\
\hline \multirow[t]{6}{*}{ Spearman's rho } & Corporate & ocialCorrelation Coefficient & 1.000 & $.927^{* *}$ \\
\hline & \multirow[t]{2}{*}{ Responsibility } & Sig. (2-tailed) & . & .000 \\
\hline & & $\mathrm{N}$ & 47 & 47 \\
\hline & \multirow[t]{3}{*}{ Organizational Resilience } & Correlation Coefficient & $.927^{* *}$ & 1.000 \\
\hline & & Sig. (2-tailed) & .000 & . \\
\hline & & $\mathrm{N}$ & 47 & 47 \\
\hline
\end{tabular}

**. Correlation is significant at the 0.05 level (2-tailed).

Source: SPSS v25: Output, 2020.

Table 1 reveals that a very strong and positive significant relationship exist between corporate social responsibility and organizational resilience with a $(r h o=0.927)$ and a PV $=0.000$ which is less than 0.05 .Thus, when organizations engages in social responsibility, their organizational resilience will increase. The degree to which corporate social responsibility influences organizational resilience is further shown in the below table 2:

Table 2: the degree of effect of corporate social responsibility on organizational resilience

\begin{tabular}{lllll}
\hline $\begin{array}{l}\text { Model Summary } \\
\text { Model }\end{array}$ & R & R Square & Adjusted R Square & Std. Error of the Estimate \\
\hline 1 & $.927^{\mathrm{a}}$ & .859 & .817 & .50611 \\
\hline
\end{tabular}

a. Predictors: (Constant), Corporate Social Responsibility

Source: SPSS v25: Output, 2020

Table 2 above reveals the degree to which corporate social responsibility influences organizational resilience with $\mathrm{R}-\mathrm{val} .=0.927$ which implies a very strong relationship while the $\mathrm{R}^{2}=0.859$ implies that corporate social responsibility explain $85.9 \%$ variation in oil and gas firms' resilience while the remaining $14.1 \%$ could be due to the influence of other factors not included in this study. The relationship is further tested applying t-statistics as shown in Table 3 below:

Table 3: T-value result on corporate social responsibility and organizational resilience

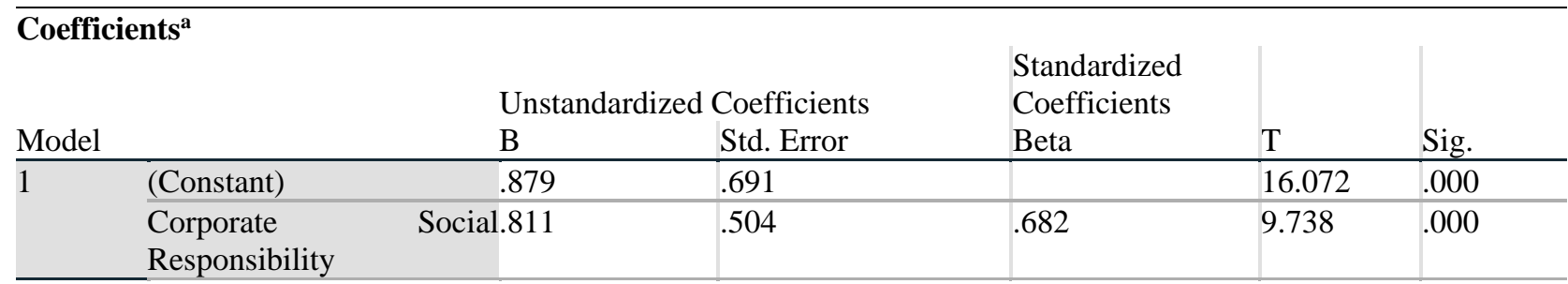

a. Dependent Variable: Organizational Resilience

Source: SPSS v25: Output, 2020

From Table 1 , the PV $=0.000$ which is less than 0.05 and Table 3 shows $\beta=0.811$; $\mathrm{t}$-cal. $=9.738>\mathrm{t}$-crit. $=1.96$ at 
$0.000<0.05 \%$ which means that the relationship between corporate social responsibility and organizational resilience is statistically significant. We therefore reject the null stated hypothesis and accept the alternate hypothesis, thus there is significant relationship between corporate social responsibility and organizational resilience of oil and gas firms in Rivers State, Nigeria.

\section{DISCUSSION OF FINDING}

Having policies that integrate economic and social concerns into an organization's core strategy plays an essential role in building good reputation for such an organization needed for its survival. Thus, Ogrizek (2001) expressed that organizations who put into place an all-inclusive corporate social responsibility enjoys better market benefits and competitive advantages needed for better performance during turbulences. This is because a business enterprise with effective and efficient policies in regards to corporate responsibility often attract top talent and good public reputation which affects their capacity to bounce back from setbacks. Hence, Ehsan et al (2012) explained that in a time frame of three to five years, a business organization that have good corporate social responsibility would have better access to talented workforce, better reputation and lower capital constraints and in the long run, corporate social responsibility provides innovation and transformation during and after disruption or crisis. Through corporate social responsibility, it may be possible to not only overcome potential disruptions but transcend disruption into a better opportunities. The provisions of social responsibility therefore help organizations to enhance their situation awareness ability, reduce organizational vulnerabilities to systemic risk environments, adaptive capacity and reestablish value following the events of a disruption because organizations that are corporate social responsibility based have the interest of their stakeholders at heart. Meeting stakeholders' needs on the spot is essential in today's service economy. This, creates more pressure on organizations to assess situations quickly, decide what can be offered to stakeholders, defend what they have done, and move on to the next level. Resilient behaviours help organizations meet stakeholders needs on the spot, capture opportunities that may be otherwise be lost, and advert catastrophes by acting quickly and effectively in crisis situations (Madni \& Jackson, 2009).

More so, when a business enterprise meet the expectations of its stakeholders, the organization is highly building a thriving trust that it can draw upon in times of crisis while on the contrary, if an organization does not deliver or meet the expectations of its stakeholders and something goes wrong in times of crisis, the capability of the organization's to bounce back might be affected. For organizations to be truly resilient, they must build enterprisewide reputation competence and the entire organization needs to understand what stakeholders are thinking and when those attitudes change, they need to become proficient in meeting those changes which is the primary aim of corporate social responsibility (McWilliams \& Siegel, 2001). Good public repute is a major outcome of corporate social responsibility that is very essential to attaining organizational resilience during crisis and turbulence. Resiliency is a seal for an organization if managed effectively and efficiently. Business organizations are often adjudged by how well they forestall changes or crisis and plan for them and, when they eventually happen, how well they adapt to them is very essential which can be achieved by having an effective and efficient corporate social responsibility policies in place .

\section{CONCLUSION}

Based on the data analyzed, we therefore conclude that corporate social responsibility has positive and significance effect on organizational resilience of oil and gas firms in Rivers State, Nigeria. Thus, corporate social responsibility is a major driver of organizational resilience. Organizations of all types and sizes especially the oil and gas firms can strengthen their resilience by engaging in corporate social responsibility activities. There are different reasons an organization indulges in a socially responsible activities such as humane intentions, positive effect on employee motivation, retention and recruitment or customer-related motivations and so on but no matter what the reasons are, it is for a better corporate reputation which is very essential to organization resilience. Therefore, organizations especially the oil and gas firms should not trivialize corporate social responsibility.

\section{RECOMMENDATIONS}

1. We recommend that oil and gas firms should balance and address the needs of different stakeholders in order to enhance their level of resilience during environmental changes.

2. We also recommend that oil and gas firms provide good working conditions and organizational support to motivate their employees so as they can give their best and go the extra mile to improving the organization's resilience.

3. More so, balancing and satisfying the host community need with the goal of the organization should be a major priority by the oil and gas firms if they want to continue to exist and prosper.

\section{REFERENCES}

[1] Antunes, P. \& Mourao, H. (2011). Resilient business process management: framework and services. Intelligent Collaboration and Design, 38(2), 12411254.

[2] Appiah-Adu, K. \& Amoako, G.K. (2016). The execution of marketing strategies in a developing economy: A case study of selected market leaders. African Journal of Economic and Management Studies, 17(1), 9-29.

[3] Bani-khalid, T.O. \& Ahmed, A.H. (2017). Corporate social responsibility: a conceptual and theoretical shift. International Journal of Academic in Accounting, Finance and Management Sciences, 7(1), 203-212.

[4] Carroll, A.B. \& Shabana, K. (2010). The business case for corporate social responsibility: a review of concepts, research and practice. International Journal of Management Reviews, 12, 85-105.

[5] Carroll, A.B. (1991). The pyramid of corporate social responsibility: toward the moral management or organizational stakeholders. Business Horizon, 9, 56-72.

[6] Deegan, C. \& Sam kin, G. (2009). New Zealand financial accounting. Sydney: McGraw-Hill.

[7] Deegan, C. (2009). Financial accounting theory. North Ryde: McGraw Hill.

[8] Deevy, N. (1995). Creating the resilient organization: a rapid response management programme, Eaglewood Cliff, N.J: Prentice Hall. 
[9] Denhardt, J. \& Denhardt, R. (2010). Building organizational resilience and adaptive management. New York: The Guilford Press.

[10] Ehsan, S., Kaleem, A., \& Jabeen, S. (2012). Exploring the interaction between financial performance and corporate social responsibility in Pakistani firms. Journal of Basic Applied Science, 2(10), 431-449.

[11] Friedman, A. \& Miles, S. (2006). Stakeholders: theory and practice. New York: Oxford University Press.

[12] Friedman, M. (1970). The social responsibility of business is to increase its profit. New York: Times Magazine.

[13] Gray, R. (2010). Some theories for social accounting?: A review essay and a tentative pedagogic categorization of theorizations around social accounting. Bingley: Emerald Group Publishing.

[14] Grote, G. (2009), Management of uncertainty: theory and application in the design of systems and organizations, decision engineering. London: Springer.

[15] Hilda, O., Hope, N. \& Nwoye, P. (2015). Corporate social responsibility and performance of selected firms in Nigeria. International Journal of Research in Business Management, 3(3), 57-68.

[16] Hohnen, P. (2007). Corporate social responsibility: an implementation guide for business, Manitoba Canada, International Institute for Sustainable Development (IISD). Available Online at: http://www.iisd.org/pdf/2007/CSER_guide.pdf.

[17] Hoopes, L. \& Kelly, M. (2004). Managing change with personal resilience. Raleigh: MK Books.

[18] Hossain, D.M., Salat, A. \& Amin, A. (2005). Voluntary disclosure on corporate social responsibility: a study on the annual reports of Bangladeshi companies. The Bangladesh Accountant, 47(20), 28-34.

[19] Kamrujjaman, M., \& Muhammad, H. (2015). The corporate social responsibility initiatives of the private commercial banking sector with special reference to Islamic banking in Bangladesh: An evaluation. International Journal of Applied Research, 1(5), 46-52.
[20] Madni, A.M. \& Jackson, S. (2009). Towards a conceptual framework for resilience engineering. IEEE Systems Journal, 3(2), 181-191.

[21] McWilliams, A. \& Siegel, D. (2001). Corporate social responsibility: a theory of the firm perspective. The Academy of Management Review, 26 (1), 117 127.

[22] Novrianty, K. \& Ely, K. (2015). Effect corporate social responsibility on financial performance. International Journal of Economics and Financial Issues, 5, 157-164.

[23] Ogrizek, M. (2002). The effect of corporate social responsibility on the branding of financial services. Journal of Financial Services Marketing, 6, 215-228

[24] Pearce, J. \& Robinson, R. (2011). Strategic management (12th ed.). New York: McGraw-Hill.

[25] Robb, D. (2000). Building resilient organizations. Organizational Development, 32(3), 27-32

[26] Wartick, S.L. \& Cochran, P.L. (1985). The evolution of the corporate social performance mode. Academy of Management Review, 10, 758-769.

[27] Waserman, E. (2003). A race for profit. A guide to corporate social responsibility, Mbajungle.COM.

\section{AUTHORS}

First Author - OGA, Kelechi Charles, PhD Student, Department of Management,Faculty of Management Sciences, University of Port Harcourt, Nigeria.

Second Author - EVWIERHURHOMA, Ejiroghene Daniel PhD Student, Department of Management, Faculty of Management Sciences, University of Port Harcourt, Nigeria. 